\title{
The United Nations Security Council Reforms and The Permanent Five Challenge: A Historical Perspective
}

\author{
Aderemi Opeyemi Ade-Ibijola \\ Department of Politics \\ University of KwaZulu Natal, South Africa \\ ibjemm@yahoo.com \\ DOI: https://doi.org/10.32890/jis2015.11.8
}

\begin{abstract}
The manner in which the United Nations Security Council (UNSC) is presently constituted remains the greatest challenge to the realization of the ambitions of UNSC permanent seat seekers. For the highly influential economic giants better known as the "middle powers"Japan, India, Brazil, and Germany; and African leading contenders such as Nigeria, South-Africa and Egypt ambitions to yield the desired result, they must mandatorily secure the support of the UNSC Permanent five veto holding members. In light of the foregoing, this paper examines the attempts to reform the UNSC since the late 1960s and the roles of the Permanent five members of the UNSC such as Britain, China, France, USA and Russia regarding this endeavour. Specifically, it argues that the Permanent five member's disposition to this issue has been the major challenge to the much desired reform of the UNSC. The UNSC is the main organ of the United Nations (UN) that is vested with powers to maintain international peace and security. Since its creation in mid 1940s, this organ has been criticized for its undemocratic nature by member states whose region are either not represented in the Security Council (SC) or under-represented.
\end{abstract}

Keywords: United Nations Security Council, Security Council, United Nations General Assembly, General Assembly, Permanent five, United Nations.

\section{Introduction}

If there is one organ of the United Nations (UN) system that has faced huge criticisms since the organization came into existence, that organ is the Security Council (SC). Over the years, the SC has been a subject of unceasing criticism because of its little size, exclusive nature, and its relations with the General Assembly, its working methods, and its undemocratic structure. Okhovat (2012). Consequently, most criticism has been directed at the infamous 'veto power', holding club that allows the five permanent members of the SC namely (Britain, China, France, USA, and Russia) to veto any proposal that negates their national interests with their veto power regardless of the popularity of such proposals and the level of international support and acceptability. Once it collides with their national interests, the 
Aderemi Opeyemi Ade-Ibijola

veto power will be invoked to thwart such proposals. Thus, the veto holding Permanent five of the SC have used their veto power more as an instrument of political vendetta. This was the case during the Cold War and colonial eras. Okhovat (2012) argues that since the establishment of the Security Council, permanent members have used their power of veto in accordance with their national interests. In the light of the synopsis presented above, this paper examines the challenge posed by these powerful permanent members of the UNSC to the popular demand for the enlargement of the SC organ of the UN. To this end, this paper was examined under three sections namely: Introduction, the UNSC Reform and the permanent five challenges, and Conclusion

\section{The UNSC Reform and the Permanent Five Challenge}

This section examines the attempts to review the UN Charter since the late 1960s and the roles played by the UNSC permanent five, and some member states of the UN in this regard. As mentioned in the foregoing, the current structure of the UNSC permanent membership consists of China, France, Russia, Britain, and the United States. Each enjoys the right to veto any proposal or decision that negates their national interests regardless of the popularity of the proposal. Apart from its Permanent five memberships, the UNSC also comprises of 10 non-permanent members elected by the General Assembly for 2 year terms. Under the UN Charter, the SC has the primary responsibility for the maintenance of international peace and security, and as discussed earlier in the chapter, it is the only UN organ that can take decisions that will be binding to all UN members. For the desired reforms to take effect, the UNSC permanent members mentioned above must ratify any changes or structural alteration to the UN Charter, including changes to the Council's size or powers. ${ }^{1}$ The question then arises, what have been the responses of the Permanent five members to issues of the SC reform over the years?

The above question is instructive and engaging. First of all, it is important to stress that the nature of international politics ordinarily compels sovereign states which make up the international system to act in the pursuit of their national interests. In doing so, states maximize and even monopolize power to their own advantage whenever they are in a position to do so. In the process, they often ride on the less powerful states to have their way. According to the realists' proponents, international politics is principally driven by states national interests thus states actors use all the available instruments at their disposal to ensure that their state's interests are secured even if it means doing so at the expense of another state - which invariably is the case.

Against this background, this section will examine the efforts that have been made since the late 1960s towards amending the UN Charter. The section also discusses the attempt by the UN Permanent five members to preserve the status quo with regard to the structure of the UN. The roles played by Nigeria (as mentioned above) and other African and UN member states in the process of reviewing the UN founding Charter also come under focus. On 21 
November 1969, Colombia, in a memorandum to the President of the General Assembly, (GA) made a request for the "establishment of a Special Committee to consider suggestions for revising the Charter of the UN". ${ }^{2}$

Ghana and Nigeria, the two most outspoken African states at the UN from the early 1960s made amendments to the Columbian "suggestion" to read "need to consider suggestions regarding the review of the Charter." 3 This was accepted, placed on the agenda of the session, and subsequently discussed by the GA. In light of this, Colombia, Chile, Guatemala, Nicaragua, and Trinidad and Tobago strengthened the initiative further by requesting in the operative paragraph of their draft resolution, that the GA "decide to include an item entitled "need to consider suggestions regarding the review of the Charter of the UN."4 The request was to be inscribed on the provisional agenda of the GA $25^{\text {th }}$ regular session of 1970. In the operative part of another draft sponsored solely by Ghana, the Secretary General was requested to invite all member states to "submit to him prior to 30 June 1970, any suggestions they considered appropriate concerning the review of the Charter." 5

The Ghanaian draft also requested the Secretary General to make suggestions available to the Committee for the $25^{\text {th }}$ Anniversary of the UN and to invite that Committee to make report to the GA at the $25^{\text {th }}$ regular session. ${ }^{6}$ The suggestion by Ghana that the Committee for the $25^{\text {th }}$ Anniversary be mandated to consider suggestions for the review of the Charter won considerable support albeit temporarily as event that ensued years later suggest a reversal of the support initially given by great powers such as Britain, United States and countries such as Italy. The Ghanaian initiative on the review of the Charter was opposed by countries such as Brazil, Iraq, Japan, Mexico, and Venezuela.

Ironically the duo of Brazil and Japan that joined in opposing the Ghanaian suggestions for reforms are now among the global economic powerhouses campaigning vigorously for permanent membership seats on the UNSC. With regard to the Ghanaian suggestion, the communist states of USSR and Hungary argued that "it was less important to make changes in the Charter than to induce those countries that shunned the provisions of the Charter to observe them scrupulously."7 Implicitly, the USSR and its satellite state of Hungary preferred that members states of the organization act in accordance with the dictates of the Charter rather than canvass for its review. France on its part held the view that subjecting the Charter to a review had the potential of weakening or even destroying its balance. At the end of deliberations, the Ghanaian delegation had to withdraw its draft resolution, following the rejection of the draft by the Sixth Committee.

Consequently, the expectation that the UN Charter would be allowed to undergo a reform was thwarted. The GA decided afterwards to postpone the discussion of the item until its $25^{\text {th }}$ session scheduled for $1970 .{ }^{8}$ The need for a review of the Charter was considered during the debate in 1970 and the P5 members of the SC kicked against it. Leading the Western bloc in opposing a reform were the United States and France who both cautioned against tampering with the Charter. The Eastern bloc opposition to a reform/review was led 
by the USSR who maintained its previous stance on the issue. This time around, it stated unequivocally that the problem was non-observance of the purposes and principles of the Charter and that there was no problem with the UN Charter as it was. Voting later ensued on the issue, on the basis of a roll-call vote of 69 to 12, with 12 abstentions; a draft resolution was later adopted by the Sixth Committee and also by the plenary. ${ }^{9}$

The content of the resolution which followed requested that the Secretary General invite Member States to send in a report indicating their views and suggestions on the item of review before July 1972, and that the item be placed on the agenda of the $27^{\text {th }}$ session of the GA scheduled for $1972 .{ }^{10}$ At the $27^{\text {th }}$ session of the GA, comments from the 32 member states were reproduced in line with the request made by the Assembly at the previous session on 11 December 1970. This was followed by an intensive debate but prior to that, it became known to delegates at the session that the reform matter would be debated under three definitive headings. To this end, three groups of opinion emerged on the matter. The first group, were the opponents of review, whether general or partial, the second, were the proponents of general review; and third was the proponents of case by case approach to the review. ${ }^{11}$

The thoughts of the opponents of a general review stemmed from their conviction that a reform/review of the Charter could threaten the efficiency of the organization hence they called on all members to respect the Charter provisions and act accordingly to its letters. Interestingly, most of the countries that supported this position were communist states. This is instructive given that it was during a Cold War period. These countries were: USSR, Bulgaria, Byelorussian, SSR, Cuba, Czechoslovakia, Hungary, Mongolia, Poland, and Ukrainian SSR, etc. ${ }^{12}$ The countries which were in favour of General review of the Charter were: Brazil, China, Colombia, El Salvador, Ghana, Indonesia, Italy, Japan, Philippines, Tunisia, etc. Those in favour of a case-by-case approach to the review were: Australia, Belgium, Canada, Denmark, Egypt, Finland, Mexico, the Netherlands, Nigeria, Sweden, United Kingdom, United States, and Syria. ${ }^{13}$ Two facts can be deduced from the above. First was the inability of the so-called third world countries at the time to unite and form a formidable opinion on the issue which would have gone a long way to advance and strengthen the agitations for a review. The Member States of the UN from the third world countries at the time felt less concerned about the review of the Charter perhaps due to the fact that the eventual success of the exercise would be of no benefit to their countries hence their lukewarm attitude to the issue.

As Bola Akinterinwa puts it, "Even when the issue was tabled for discussion, many . . . countries have not been very forthcoming." 14 Second was the apparent inability or lack of proper articulation on the part of the Nigerian state for a review of the Charter at that session. For a country whose foreign policy ambition is driven by the desire to lead Africa in every respect, many would have expected such a country to strongly make a case for the African continent in this regard. Again, Akinterinwa corroborated this view when he noted that “. . . Nigeria's position was not good enough. Nigeria supported an ad hoc approach to 
the discussion of the issue. It is difficult to imagine how an ad hoc review of the Charter, when considered necessary, could be in Africa's long term future." ${ }^{15}$ This points to the fact that Nigeria's sterling record and reputation in the UN (especially on African decolonization issues) and other issues were not without low moments. Another hurdle the advocates of review of the Charter faced during this time was the crisis of over politicization and conflict of interests.

However, they pursued their objective with unyielding tenacity at the session to the extent that they gave their support to the establishment of a Special Committee to consider the comments and proposals presented by Member States; however, their plan to have the Charter reviewed was thwarted when it became known that a handful of responses were received from countries that had been asked to make comments and present proposals on the Charter (Akinterinwa, 2005). With this stalemate, the three draft resolutions submitted to the Sixth Committee (Legal) noted expressly that the Secretary General inquiry into the review of the Charter which was pursuant to resolution 2697 (XXV) of 1970 have been observed to have received replies from less than quarter of the governments of Member States and that no general trend of opinion in the United Nations can be deduced from these replies, recognizing that a review of the Charter which suffers from popular support would militate against the desired results, that is, the strengthening of the effectiveness of the United Nations itself. ${ }^{16}$

The GA therefore requested the Secretary General to invite Member States that had not already made their position known on the issue to do so and communicate to him, before 1 July 1974, their views with regard to the desirability of a review of the Charter of the $\mathrm{UN}$ and their actual suggestions in this respect ${ }^{17}$. The GA further requested the Secretary General to submit to the Assembly at its $29^{\text {th }}$ session scheduled for 1974 a report setting out the views and suggestions of the Member States which have been communicated to him as directed. The GA sitting ended with the decision to include in the provisional agenda of the $29^{\text {th }}$ session an item entitled, "Need to consider suggestions regarding the review of the Charter of the United Nations." ${ }^{18}$ Implicit from the above is the fact that the absence of political will on the part of both the great powers and the huge contingent of third world Members states were contributory factors to the failed attempt to review the Charter.

The issue of the Charter review/reform was not considered by the GA at the 1974 session. It had earlier indicated that the issue would be tabled for discussion at the session. Thus, the status quo remained until 1979 when Nigeria and nine fellow Member States of the UN took cognizance of the fact that since the 1963 amendment to the Charter which resulted in the expansion of only the non-permanent membership of the UNSC from 11 to 15 , membership of the organization had increased significantly from 113 to 152 states. However, it regretted that these changes had not been reflected in the UNSC membership. As a result of the glaring reality, Nigeria and other nine countries consequently in a letter dated 14 November 1979, requested for the inclusion of the "Question of equitable representation on and increase in the membership of the Security Council" on the agenda of that session which was at the time ongoing (Akinterinwa, 2005:43). 
In the said letter, the statistical breakdown of the global average of one non-permanent seat representation on the UNSC was presented to drive home the point. As it turned out, the global average was put at 14.7 countries, the number of Asian countries represented by one non-permanent seat stood at 18.5 while that of African States was put at 16.3. The Latin American countries had 14, 11 went to Western Europe and other countries and finally 10 for Eastern Europe. ${ }^{19}$ As the request was being considered by the General Committee, the United States proposed an amendment that sought to inscribe as part of an agenda item on the Special Committee on the Charter of the UN and on the strengthening of the role of the world body. The amendment suffered rejection afterwards as the General Committee decided the fate of the amendment by 13 votes against 7 in favour, with 3 abstentions on 27 November 1979..$^{20}$ The Committee later recommended the inclusion of the request made by Nigeria and others in the GA's current agenda by 19 votes in favour, 5 votes against and 2 abstentions.

This was followed by the GA's acceptance of the Committee's recommendation by a recorded vote of 83 to 14 with 9 countries abstaining on 28 November $1979 .{ }^{21}$ In the letter of request, the quest to amend Article 23 of the UN Charter in order to accommodate an increase in membership was expressed in clear terms. Thus, the letter and its sponsors wanted the non-permanent membership seats to be increased from 10 to 14 . In this regard, the 14 non-permanent members were to be elected as follows: 4 from Africa; 3 from Asia; 1 from Eastern Europe, 3 from Latin America, 2 from Western Europe and other countries; while 1 seat was to alternate between Africa and Asian States. This proposal was scheduled for ratification by all Member States by 1 September $1981 .{ }^{22}$

The Latin American countries were not left out in the advocacy for review/reform of the Charter as Bolivia, Chile, Colombia, Costa Rica, the Dominican Republic, Ecuador, Guatemala, Panama, Peru and Venezuela, submitted an amendment that sought to increase the membership of the UNSC non-permanent seat to 21. In this respect, the Latin American contingents proposed the reconstitution of the UNSC as follows: 16 non-permanent seats, and the retention of the existing 5 permanent seats. By supporting the retention of the P5 club, the Latin group erred in the sense that they further contributed to the hitherto failure of the third world countries to take a popular stance on the issue which as earlier argued, could have helped put pressure on the dominant forces that controls the UN - the P5 to recognize and act in accordance with their request. In order words, apart from the P5 members' albatross in the review/reform process, the role played by the third world countries during these periods was also a contributory factor which helped to retain the Status quo in favour of the P5 'oligarchs'.

The Latin group gave a breakdown of their recommendations as follows: 5 non-permanent seats for Africa, rather than the prior proposed 4; 1 non-permanent to alternate between Latin America and Asia; and another non-permanent seat was to alternate between Eastern, Western European countries and other countries. In any case, 13 affirmative votes would be needed for adoption of decisions. As deliberation progressed on this proposal, India gave 
a suggestion that the matter should be postponed until the 1980 regular session of the GA because in the words of country's delegation it could no longer be 'pressed' at the session. ${ }^{23}$ The Indian suggestion was subsequently adopted by the GA in its decision 34/431 of 14 December, $1979 . .^{24}$

From the early 1980s, the "Question of equitable representation on and increase in the membership of the Security Council and related matters" became a routine subject of discourse on the agenda of the GA although; the matter was during this decade treated without concrete interest at the GA sessions. In 1981, no action was taken on the question of equitable representation on an increase in the membership of the UNSC as many would have expected it to be. Deliberations on this question were postponed until the 1982 GA annual session. Again at the 1982 session, the GA was not forthcoming on the issue of review/ reform for the second successive year. The only thing the Assembly did in this respect was to put the item on its 1983 provisional agenda of the $38^{\text {th }}$ annual session on the excuse that "no request for consideration of the matter had been made during the session." 25 Again, this goes to buttress the prior argument made in this chapter that the third world countries were non-enthusiastic about the issue of the review/reform of the Charter. Otherwise, they would have raised the issue for discussion at the 1981, 1982; and in other subsequent sessions of the GA.

The presidency of the GA during that decade also failed spectacularly in this regard because of the fact that the issues of review/reform had been a pending issue before the GA since 1979 and 1980 hence the issue ought to have been raised for discussion and treated as issues arising from past sessions and not just act on the flimsiest of excuses that the issue was not raised for consideration by any member state hence the decision to table the issue in the plenary sessions.

The grave - like silence maintained on the issue was symptomatic of a behind the scene machinations by the powers that be at the UN to kill the review/reform initiative. The fact that the issue was no longer raised at the GA for upward of 7 years coupled with the general silence of the P5 members on the issue - who ordinarily would not have been silent if the issue concerned all serve as prove. As implied above, the issue was not discussed at the GA sessions from 1981 to 1985. For instance, at the 1983 and 1984 regular session of the GA the issue was not considered at all. However, at the $105^{\text {th }}$ plenary session held on 18 December 1984, the GA in its decision 39/455 put the question of equitable representation on the provisional agenda of its $40^{\text {th }}$ session scheduled for 1985. Even at the 1985 and subsequent sessions held before the $48^{\text {th }}$ session in 1993, the question of equitable representation on and increase in the membership of the UNSC was not presented for deliberations at the GA (Akinterinwa, 2005).

The next deliberation on the issue of reform was during the commemoration of the $50^{\text {th }}$ anniversary of the UN in 1995 when the UNGA approved the Declaration of the United Nations, stating expressly that the SC should be "expanded and its working methods 
continue to be reviewed in a way that will further strengthen its capacity and effectiveness, enhance its representative character, and approve its working efficacy and transparency." ${ }^{26}$ Two years after, the Malaysian UN Ambassador Ismael Razali, who also was the President of the GA 1996-1997; and the then Chair of the Open-Ended Working Group presented a proposal suggesting the addition of a non - veto holding five permanent seats and four non-permanent seats to the SC. The Malaysian envoy's proposal which allowed the UNGA to pick the countries it deemed eligible to take up the proposed seats was later blocked by members of the NAM and a host of other member states of the UN such as Egypt, Italy, Mexico, and Pakistan (Bourantonis, 2005). Razali's proposal was blocked by the NAM group which saw the plan as a threat to their internal cohesion, along with Italy, who sought to block the permanent membership bid of Germany and Japan. ${ }^{27}$ The Italian opposition to Germany and Japan's SC permanent membership bids is historically ironic given the fact that the trio of Italy, Japan, and Germany were allies during the Second World. The enviable economic and technological successes which have been recorded by Germany and Japan might have played a major role in Italy's continued opposition to its ex-allies bids for SC permanency. Tokyo and Berlin occupy the third and fourth positions respectively in the global ranking of the World's most powerful economies. ${ }^{28}$

Following a decade of intensive agitations and debates for the SC reform, the UN SecretaryGeneral Kofi Annan in 2003 set up a 16-member high level panel to consider and recommend the appropriate options for the restructuring of the SC. In 2004, the panel came up with recommendations which proposed two different options for the SC restructuring which are as follows: Option (A) six new permanent seats without veto power and three additional non-permanent seats; Option (B) eight four year renewable seats and one additional non - permanent seat (Blum, 2005, Price, 2005). The UNGA debated these options and others passionately for the better part of year 2005; they were, however, unable to reach a consensus on how to restructure the SC. The African Union (AU) on its part responded to these proposed options by choosing the first option following the decision of the Heads of States and Governments of Africa in their mid-term submit in Abuja, Nigeria in January $2005 .{ }^{29}$ This position was subsequently ratified and adopted by the African continental organization on 8 March 2005, in Addis Ababa, and became the African continent official position with regard to the reform of the SC. ${ }^{30}$

The effect of the failed attempt to restructure the SC in 2005 was a frustrating experience. In the words of Brazilian Ambassador Ronaldo Mota Sardenberg whose country nurses a permanent seat ambition for the SC, the debates on the reform of the SC hit the rock because a "few countries, seeking to avoid any decision on this matter, take refuge on claims for consensus and on allegations on the disruptive nature of the issue." ${ }^{31}$ Implicitly, some states were non-assertive on the issue perhaps due to their naivety or acting under the influence of some powerful states that might have dissuaded them from taking part actively in the process of the SC reform debates. According to Ambassador Sardenberg, the actions and disposition of these countries with regard to the issue of the SC reform "only contribute 
to the perpetuation of current inequalities in the structure of the organization, and to the frustrations of the aspirations of all members, for a more balanced distribution of power in the work of the Security Council." ${ }^{32}$

\section{Conclusion}

The paper has discussed the attempts made towards reforming the UNSC from the 1960s to the mid-2000s. It held the view that the institutional landmines which had been set by the virtue of the veto powers vested in the Permanent five members is largely responsible for the failed attempt to reform the UNSC. Even recent opinions on this issue suggests clearly that the composition of the UNSC permanent membership veto club remains the greatest challenge to the actualization of the dreams of those countries seeking the permanency of the SC. As JM Simon observed in 2011: "The UNSC was . . designed for a very historical reality and is as such not prone to enlargements or democratizations. With the veto power as its main decision-making characteristic, the architecture of the SC doesn't provide any incentive for change. .."33

Consequently, the conclusion drawn by his paper is that the UN itself seems not to be favourably disposed to carrying out the much needed SC reforms. As enshrined in its Charter, the requirements for the expansion of the SC permanent seats will be fulfilled when aspiring permanent membership seeking countries secure the nod of not less than twothird of the entire membership of the UN, and the votes of all the Permanent five members to ratify an amendment to the UN Charter. This pIaces the ambitions of the UNSC seekers in a dicey situation because the UNSC permanent five members will still be the ultimate decider when the time finally arrives for the Council's seats to be expanded. However, the reform of the UNSC is not yet beyond the realm of possibility given that China was not a permanent member of the UNSC until the 1970s when it was invited to join the fold in place of the other China, namely Taiwan. Thus, aspiring countries should continue to push for a permanent representation on the UNSC using all available diplomatic and political approach. If China could make it, they also can.

\section{End Notes}

1. Cited by Akinterinwa B. A. (2005).Nigeria and the permanent membership of the United Nations Security Council: Dynamics and definienda. Vantage Publishers Ltd, Ibadan, Nigeria, p. 41. NB book title in italics!

2. Ibid.

3. Ibid.

4. Ibid.

5. Ibid.

6. See United Nations General Assembly Resolution 2552 (xxiv), A/7870, 12 December, 1969.

7. Ibid. 
8. Ibid.

9. See the Yearbook of the United Nations, Vol. 24, 1970, p. 299.

10. See the yearbook of the United Nations, Vol. 26, 1972, p. 221.

11. See the Yearbook of the United Nations, Vol. 24, 1970.

12. Ibid.

13. Akinterinwa B. A. (2005). Nigeria and the permanent membership of the United Nations Security Council: Dynamics and definienda," Vantage Publishers Ltd, Ibadan, Nigeria, p. 42.

14. Ibid.

15. See United Nations General Assembly Document, 2109 ${ }^{\text {th }}$ Plenary Meeting, 14 December 1972.

16. Ibid

17. Ibid

18. Akinterinwa B. A. (2005). Nigeria and the permanent membership of the United Nations Security Council: Dynamics and definienda. Vantage Publishers Ltd, Ibadan, Nigeria, p. 44.

19. Ibid.

20. Ibid.

21. Ibid.

22. Ibid.

23. United Nations General Assembly Official Records 34/431, 14 December, 1979.

24. Akinterinwa, B. A. (2005). Nigeria and the permanent membership of the United Nations Security Council: Dynamics and definienda. Vantage Publishers Ltd, Ibadan, Nigeria, p. 45.

25. p. 45.

26. Ibid. p. 38

27. See Gordon N. (2014, May). Pathways to Security Council reform. Center on International Cooperation, New York University, United States. Retrieved from: www.cic.nyu.edu.

28. GDP Current US\$. (2013). World Development Indicators World Bank.

29. See H. A. Saliu and J. S. Omotola. (2008). Can Nigeria get a UN Security Council Seat? South African Journal of International Affairs, 15(1), June.

30. Ibid.

31. Cited by J. E. Guzzardi and M. J. Mullenbach (2007-2008). The politics of seeking a permanent seat on the United Nations Security Council: An analysis of the case of Japan. Midsouth Political Science Review, 9, 38.

32. Ibid., p. 38.

33. See Simon J. M. (2011). An EU seat in the Security Council as first step towards a democratic organization of world security. Retrieved from: http:www.simonlluma.eu/2011/06/an-eu-seat-inthe-security-council-as-first-step-towards-a-democratic-organization-of-world security, p. 2 